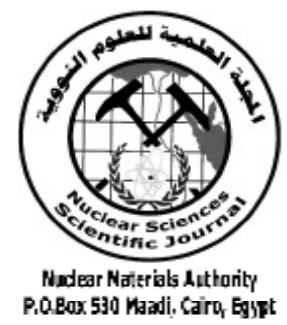

ISSN 2314-5609

Nuclear Sciences Scientific Journal

vol. 4, p 115-132

2015

\title{
GEOLOGY AND RADIOACTIVITY OF ALKALINE GRANITES OF SOUTHWEST GABAL NUSAB EL BALGOUM AREA, SOUTH WESTERN DESERT, EGYPT
}

\author{
ADEL A. ARBAB; NASSER M. MOGHAZY and ATA ABDELSHAFY \\ Nuclear Materials Authority, P.O. Box: 530 El-Maadi, Cairo, Egypt
}

\begin{abstract}
This paper is concerned with the geology and radioactivity of alkaline granites southwest Gabal Nusab El Balgoum area, South Western Desert, Egypt. The alkaline granites are equigranular in texture, fine- to medium-grained and dominated mainly by perthitic orthoclase and quartz, aegirine-augite, aegirine, and plagioclase, while Bastnaesite, xenotime, calcite, monazite, zircon and apatite are accessory minerals. Opaques represented by Hematite, ilmenite, goethite and little sulphides (chalcopyrite and pyrrhotite). Applying alpha-track emission technique indicates that iron oxides and altered feldspar minerals contain great amount of radio-elements ( $\mathrm{U}$ and $\mathrm{Th}$ ). Representing field radiometric contour maps for eU, eTh (ppm) and $\mathrm{K} \%$ indicate that $\mathrm{U}$ and $\mathrm{Th}$ concentrate in the main fault trend NE-SW, which suggest that the enrichment of $U$ is structurally controlled. A difference between field measurements (eU and eTh) with the chemical analysis data ( $U$ and $T h$ ) can be explained due to recent $U$ addition. The trace elements contents show that $\mathrm{Zr}, \mathrm{Nb}, \mathrm{Y}$ (HFS elements) values increase with increasing $\mathrm{U}$ due to hydrothermal alteration at later stages of magmatic activity. Chondrite normalized REE diagram shows that the alkaline granite has enrichment of $\sum$ REE and display progressive enrichment in LREE relative to HREE which shows a slightly flat pattern with large negative Eu anomaly. The enrichment of REEs may be attributed to the presence of bastnaesite and monazite as a source of LREE and xenotime as a source for HREE.
\end{abstract}

\section{INTRODUCTION}

The basement outcrops of South Western Desert are often scattered and covered by thin sheets of windblown sands. In some cases the basement is in a topographically more elevated position than the surrounding sedimentary rocks, this is either the result of tectonic uplift, as in the case of Gabal Uweinat uplift itself or Nusab El Balgum (study area), or as a result of the intrusion of younger anorogenic bodies (Klitzsch and Schandelmeier, 1990). The majority of these rocks are exposed around the Gabal Uweinat-Gabal Kamil area and smaller basement inliers like the Bir Safsaf, Gabal
El Asr and Gabal Um Shaghir complexes (Klitzsch and Schandelmeier, 1990).

The study area of southwest Gabal Nusab El Balgoum is located between lat. $23^{\circ} 16^{\prime}$ and $23^{\circ} 17^{\prime} \mathrm{N}$ and long. $29^{\circ} 16^{\prime}$ and $29^{\circ} 17^{\prime} \mathrm{E}$ (Fig.1). The study area comprises volcanic rocks (alkali rhyolite), their tuffs of PermoTriassic age, which represent the oldest exposures in the study area. These volcanic rocks intruded by the alkaline granites. Generally, the alkaline granites crop out as elongated bodies with low topography trending in the NE-SW direction and are partially covered by the mobile sands. 


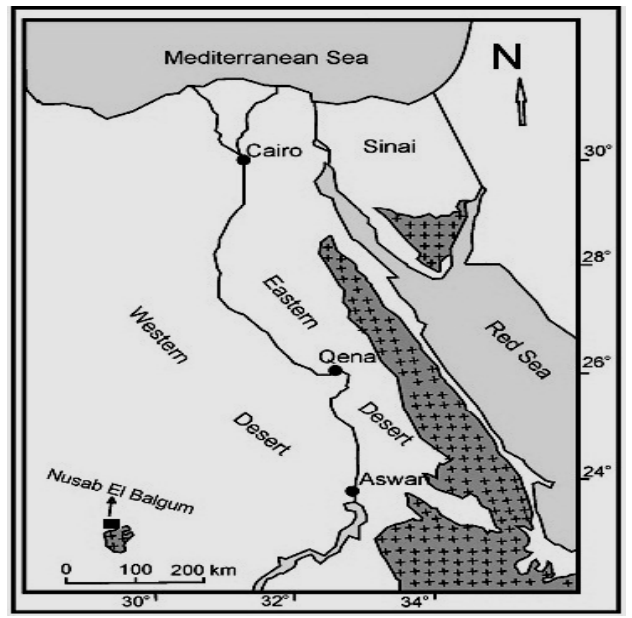

Fig.1: Location map of study area southwest of Gabal Nusab El Balgoum, South Western Desert, Egypt

The area was previously studied by many authors e.g., El Shazly et al. (1969), Vail (1976\& 1985), Bishady and El Ramly (1982), Richter (1986), Frantz et al. (1987), Richter and Schandelmeier (1990), Sakran et al. (1996), Abd El Warith (1997), Assran et al., (2012) and Abu El Atta, et al., (2013).

The main goal of the present work is to:

1- Constructing a detailed geologic map using systematic grid with lines interval of $25 \mathrm{~m}$. between lat. $23^{\circ} 16^{\prime}$ and $23^{\circ} 17^{\prime} \mathrm{N}$ and long. $29^{\circ} 16^{\prime}$ and $29^{\circ} 17^{\prime} \mathrm{E}$.

2- Characterize the features of the granitic rocks using field observation and petrographic, geochemical and radiometric studies.

3- Constructing eU, eTh and $\mathrm{K}$ distribution maps using a gamma-ray spectrometer survey instrument (model RS-230 BGO Super-Spec).

4- Deducing the factors, which controlling uranium distribution and evaluating the area from the radioactivity point of view.

\section{SAMPLING AND ANALYTICAL TECHNIQUES}

In order to achieve the above goals, the field work was preceded by Google earth maps and
Landsat images interpretation of the area. Field trips were done for detailed geologic mapping, radiometric survey and collecting representative samples. Seventeen samples were chosen for the preparation of thin sections of which five were selected for the preparation of the polished sections. The field measurements of radioactivity were done by using a gamma-ray spectrometer survey instrument (model RS230 BGO Super-Spec). Mineralogical investigations, alpha-track emission technique (Solid State Nuclear Track Detectors (SSNTD), type Kodak CN-85) were carried out to determine the minerals responsible for radioactivity. The petrography and photomicrographs were carried out using polarizing microscope equipped with a full automatic photomicrograph attachment. Polished surfaces were investigated using the Environmental Scanning Electron Microscope (ESEM) model Philips XL30 under operating conditions of accelerating voltage $30 \mathrm{kv}$ and account time 60-120 seconds with back-scattered detector (BSE). Five samples were chemically analyzed for trace elements in labs of Nuclear Materials Authority, using X' unique-II Philips X-ray spectrometer with automatic sample changer PW-1510 (30 position). Also, REEs had been detected for the selected samples using Prism ICP-OES Spectrometer from Teledyne Leeman Labs at Analyses Department of Nuclear Materials Authority. The Prism is a truly simultaneous inductively coupled plasma emission spectrometer with a wavelength range 165 to $400 \mathrm{~nm}$ that covers most commonly determined elements. Detection limits are started from $2 \mathrm{ppb}$.

\section{FIELD GEOLOGY}

The study area is about $\left(2.7 \mathrm{~km}^{2}\right)$ covered by basement rocks outcrops represented by volcanic rocks that intruded by alkaline granites. The alkaline granites are partially covered by the mobile sands (Fig.2). They are structurally controlled by NE and NNW minor faults. The volcanic rocks are the oldest exposures in the study area, are represented by alkali rhyolite and their tuffs of Permo-Trias- 
sic age, where the granitic rocks are mainly of the alkaline granites.

The alkaline granite masses are trending in the NE-SW direction with 500 meters average length (Fig.3). The alkaline granite exhibit weathering with characteristic bouldery appearance (Fig.4). They are partially covered by the mobile sands (Fig.5). Sometimes, the granites show brick-red colour due to hematization. The alkaline granite is represented by two topographic outcrops; the higher one represents the northeastern part of the mass while the southern one is relatively low. These granites intrude the volcanic rocks with sharp intrusive contacts. Neither mafic dykes nor enclaves are recorded within the alkaline granites.

The following features characterize the alkaline granites:

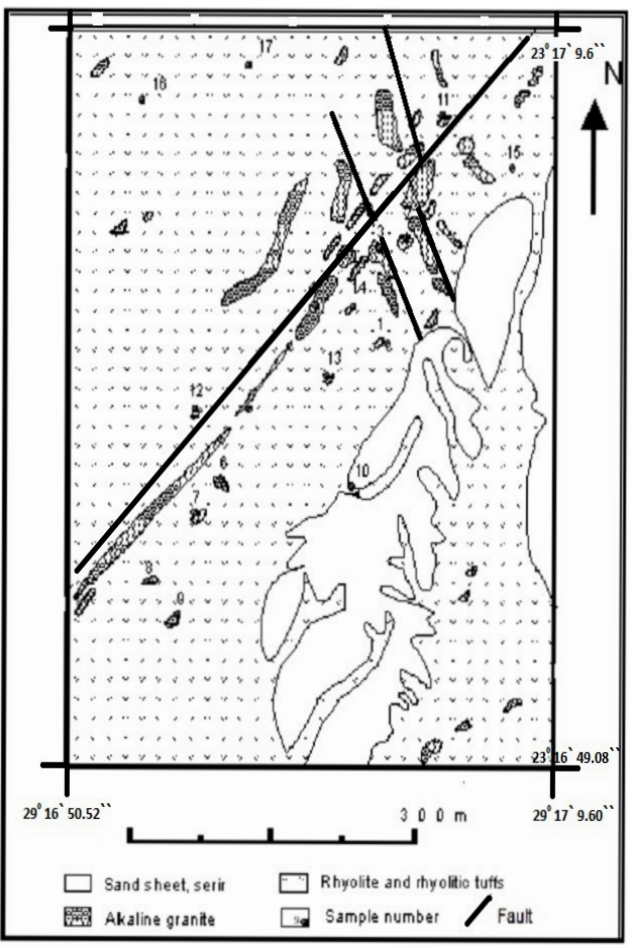

Fig.2: Geological map of southwestern Gabal Nusab El Balgoum area, South Western Desert, Egypt.

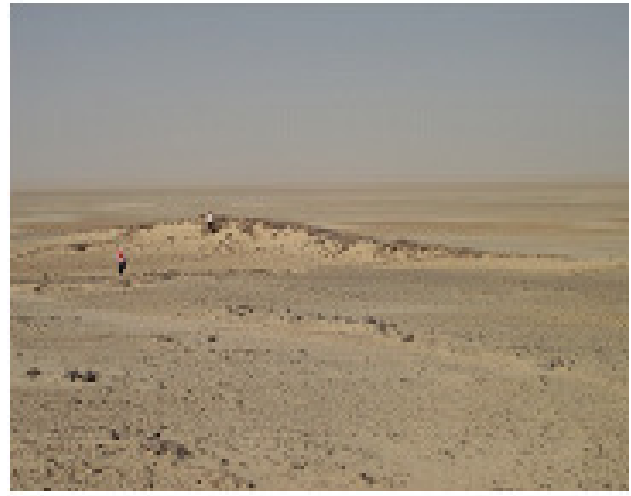

Fig.3: Elongated body of alkaline granite shows low topography trending northeast

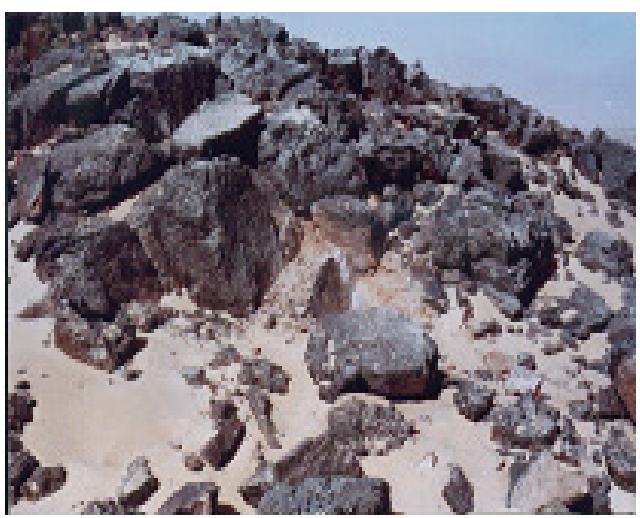

Fig.4: Blocky appearance of alkaline granites shows primary abrasion events.

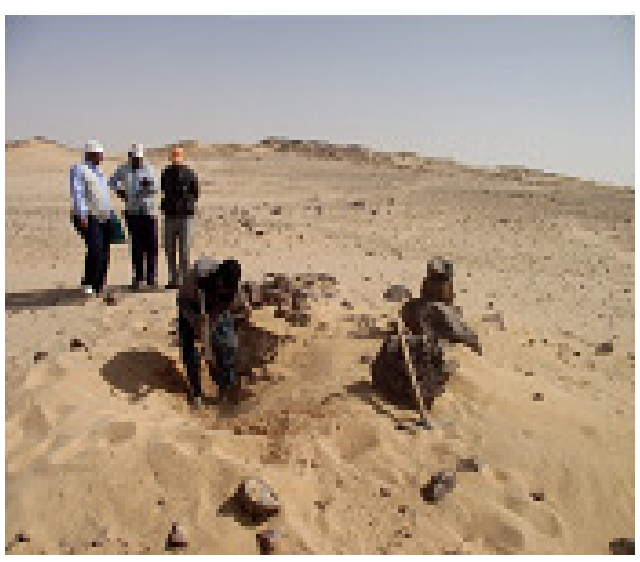

Fig.5: Alkaline granites are partially covered by the mobile sands 
1. They are massive and very hard with weathering features. They are fine- to mediumgrained with characteristic brick-red color.

2. Their contents of quartz in hand specimen are very high reaching up to $40 \%$ of the bulk rock.

3. Red jasper veinlets filling some local fractures are common.

4. Hematization alteration features are common in the lower topographic part, giving the rock reddish tint to the southern masses.

5. Cracks and minimal abrasion on the rock surface without detachment formed from bedrock (Figs.6, 7 and 8).

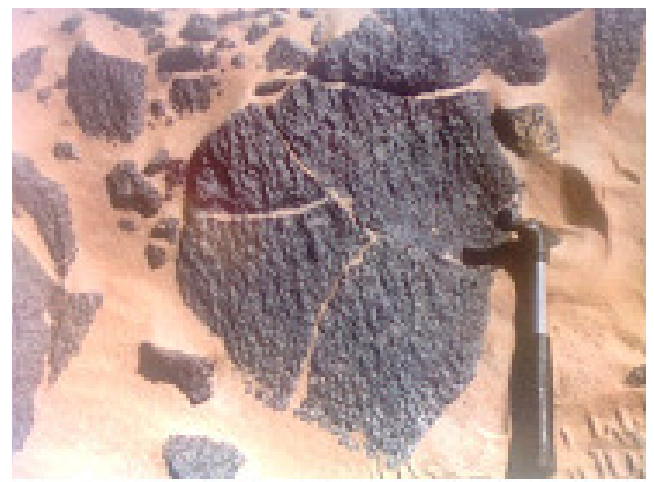

Fig.6: Cracks on the rock surface without detachment formed from impact against immobile bedrock and weathering.

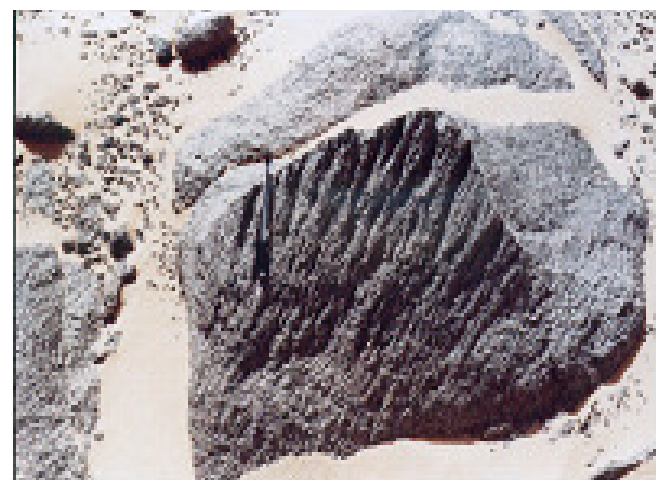

Fig.7: Near-linear depressions on low angled surface formed parallel to the wind as a result of abrasion by sand.

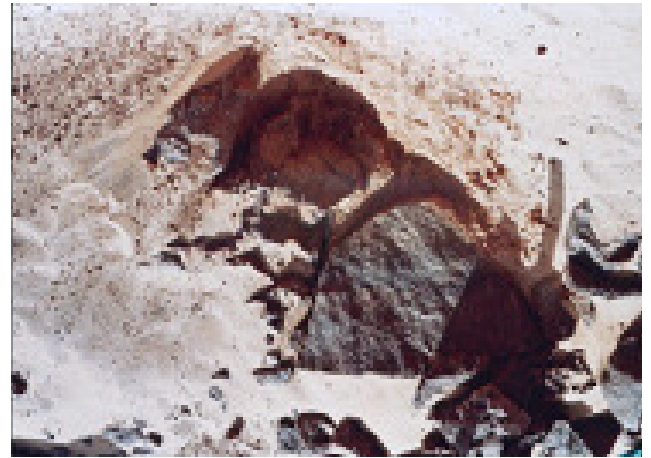

Fig.8: Minimal abrasion rock surface developed where debris has protected the rock from abrasion.

\section{PETROGRAPHY}

The alkaline granites are generally equigranular in texture, fine- to medium-grained and are leucocratic but may grade into grey to deep brownish-red in color due to staining by iron oxides. The alkaline granites are dominated mainly by perthitic orthoclase, quartz, aegirine-augite with minor aegirine, and plagioclase. Accessory minerals represented by bastnaesite, xenotime, calcite, monazite, zircon and apatite. Perthitic orthoclase occurs as euhedral to subhedral elongate tabular crystals showing patchy and string perthites (Fig.9 and 10). It is highly turbid in the altered samples (Fig.11). Aegirine and Aegirine-augite represent the main mafic minerals. Aegirine-augite is present as euhedral, elongate discrete laths or aggregates (Figs.12 and 13). Plagioclase $\left(\mathrm{An}_{2-8}\right)$ occurs as euhedral, subhedral and anhedral crystals, albite twinning is rarely absent (Fig.14). Quartz occurs as subhedral prismatic crystals, and as replacement anhedral. Aggregates of aegirine occur as radiating acicular crystals intergrown with quartz (Fig.15). Oxidation of aegirine-augite leads to form hematite staining the rock by different degrees. The aegirine-augite is replaced by fine-grained zircon, quartz and Fe-Ti-oxides (pseudomorphs). Pseudomorphs is a suggested evidence for hydrothermal alteration late- to post-magmatic evolution (Fig.16). Zircon occurs as small $(<0.1 \mathrm{~mm})$ subhedral crystals in aggregates with apatite (Fig.17). Xenotime (Y, REE, $\mathrm{PO}_{4}$ ) 


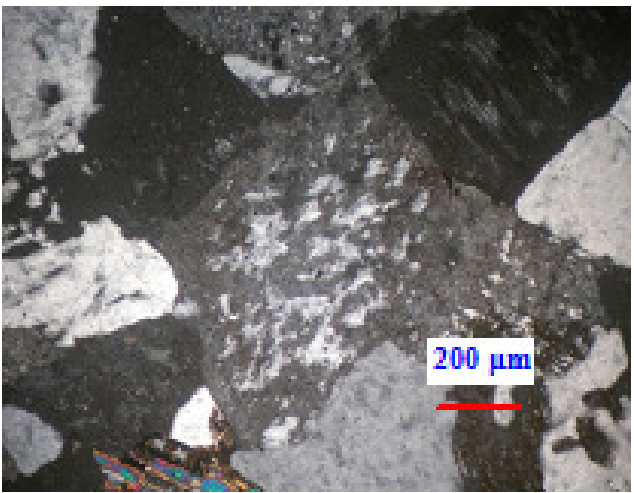

Fig.9: Patchy type perthite, XPL

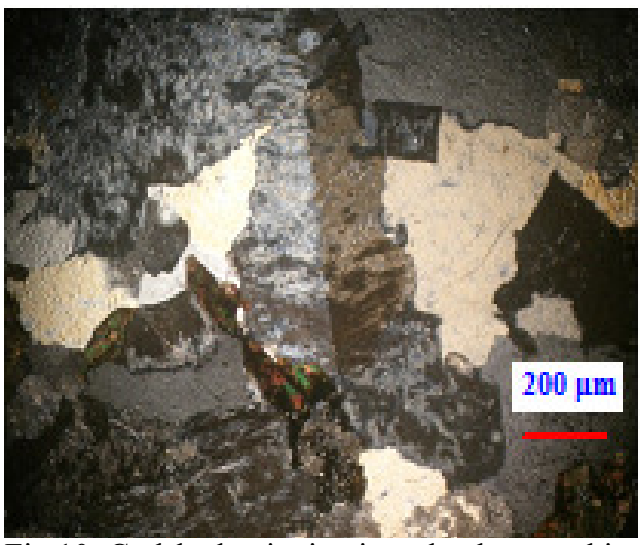

Fig.10: Carlsbad twinning in orthoclase perthite, XPL

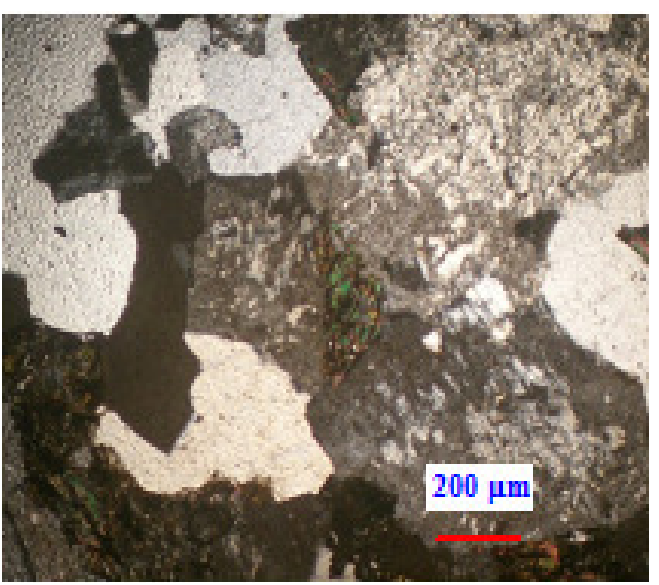

Fig.11: Perthitic orthoclase, XPL

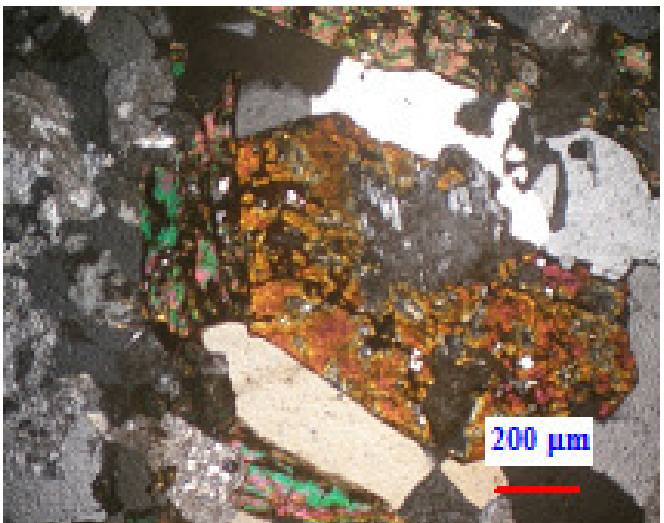

Fig.12: Aegirine-augite, XPL

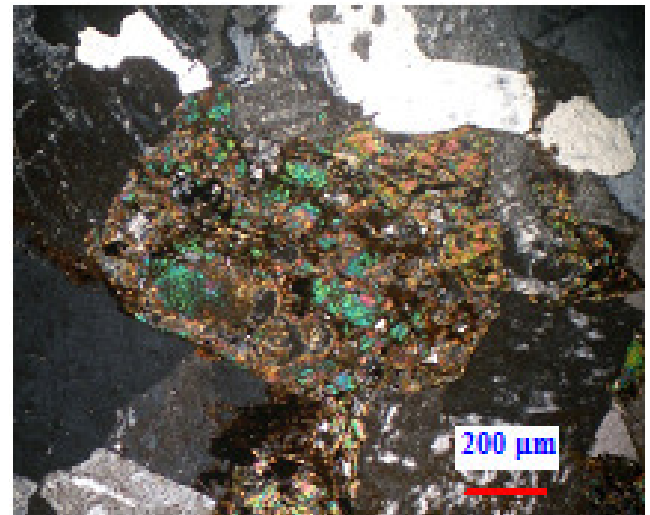

Fig.13:Aggregates of aegirine-augite,XPL

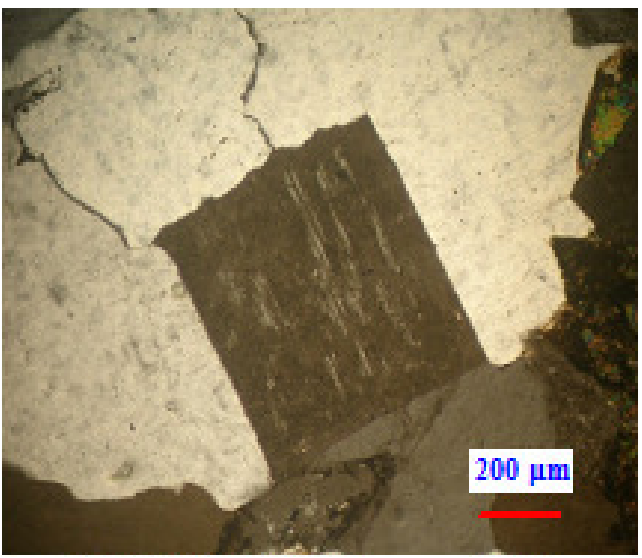

Fig.14: Euhedral plagioclase crystal, XPL 


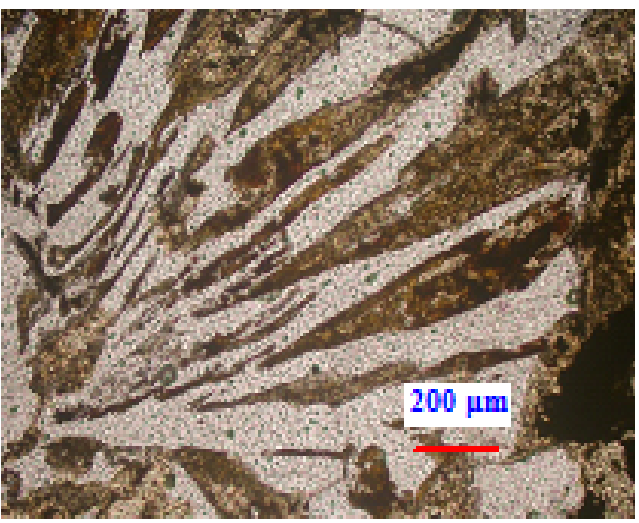

Fig. 15: Graphic intergrowth of aegirine and quartz, PPL

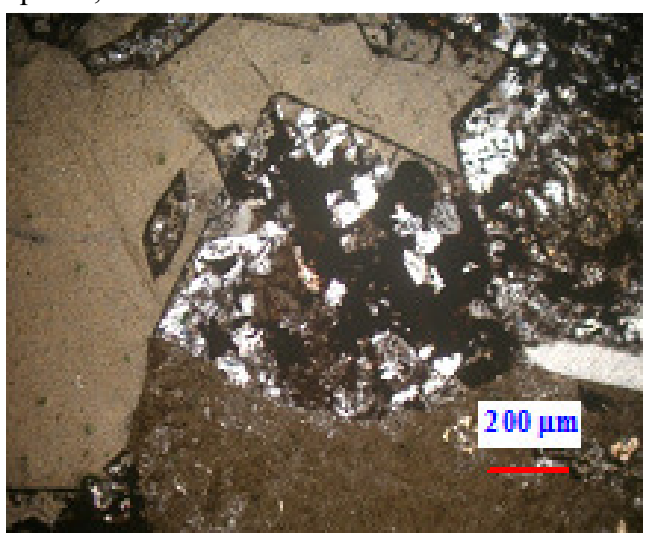

Fig.16: Aegirine replaced by pseudomorphs of quartz, zircon and iron oxides, XPL

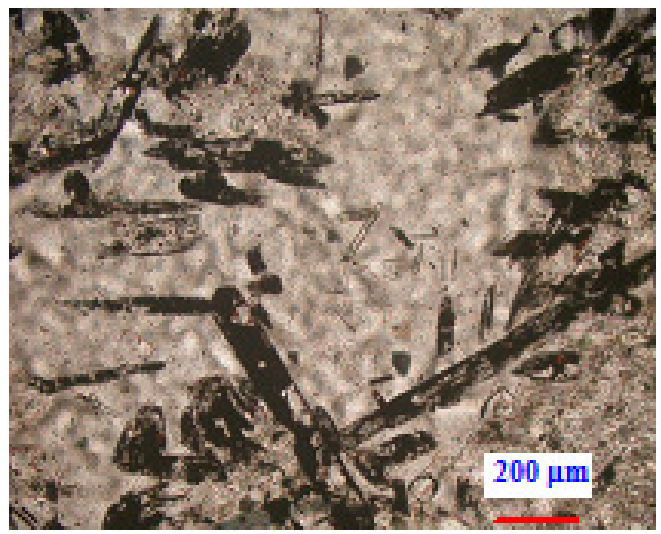

Fig.17: Aggregates of apatite and zircon in quartz, PPL usually occur as small euhedral crystals intergrown parallel with zircon. It is characterized by irregular rim zonation within host crystals (Fig.18). Bastnaesite $\left\{(\mathrm{Ce}, \mathrm{La}, \mathrm{Nd}) \mathrm{CO}_{3}\right\}$ occurs as orange to reddish short prismatic crystals (Fig.19). Monazite occurs as brown to reddish brown prismatic or tabular crystals (Fig.20).

\section{OPAQUE MINERALS}

All the studied polished surfaces of the alkaline granites are poor in opaques (up to $1 \%)$ and represented by hematite, ilmenite, goethite and little sulphides (chalcopyrite and pyrrhotite). Hematite occurs in anhedral crystals, masses and occasionally in minute scales. It is a secondary mineral due to oxidation of aegirine-augite (Figs.21, 22 and 23). Sulphides are found as minute disseminations of pyrite and chalcopyrite scattered all over the rock (Fig.24), few big euhedral to subhedral grains of goethite are found. These grains are pseudomorphous after pyrite and show colloform textures (Fig.25). Chalcopyrite occurs in a great variety of forms in association with pyrite. Its concentration has traditionally been assigned to augite. It generally occurs as anhedral interstitial grains (Fig.26), while pyrrhotite occurs as minute specks scattered in the rocks (Fig.27). Ilmenite occurs as discrete subhedral skeletal prismatic crystals partly altered to hematite (Fig.28).

\section{Alpha Track Techniques}

Mineralogical investigation using alphatrack emission indicates that iron oxides and altered feldspar minerals contain great amount of radio-elements ( $\mathrm{U}$ and $\mathrm{Th}$ ). The petrography and photomicrographs were carried out to determine the minerals responsible for radioactivity. These minerals contain minor amounts of $U$ and/or Th as indicated by the restriction of the alpha-tracks upon these minerals when matching the cellulose slabs and their equivalent thin sections. Most of tracks are traced on opaque minerals and altered feldspar stained with iron oxides. Iron 


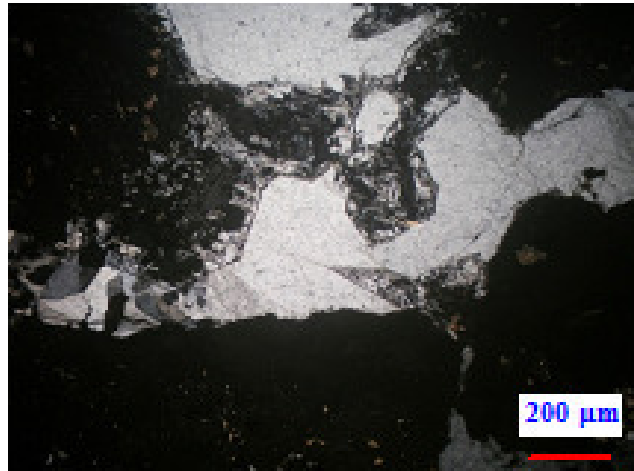

Fig.18: Prismatic xenotime crystals rimmed by hematite alteration, XPL

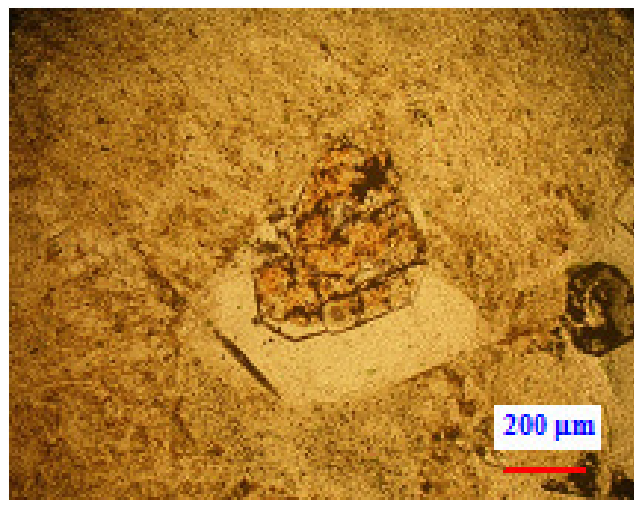

Fig.19: Bastnaesite crystal, PPL

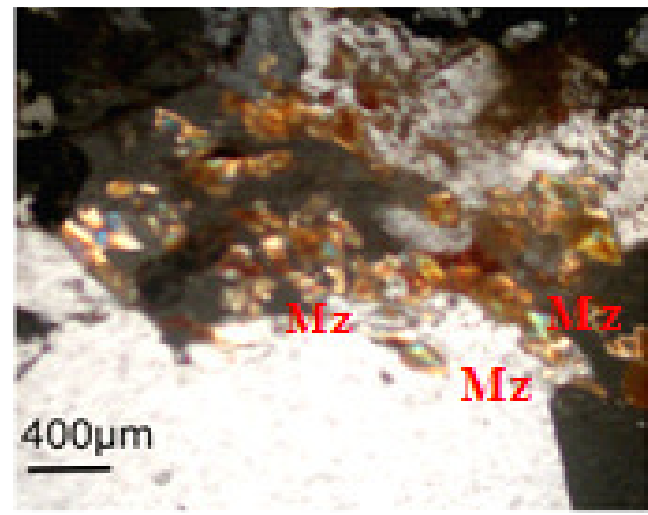

Fig. 20: Aggregates of monazite (Mz) crystals, XPL

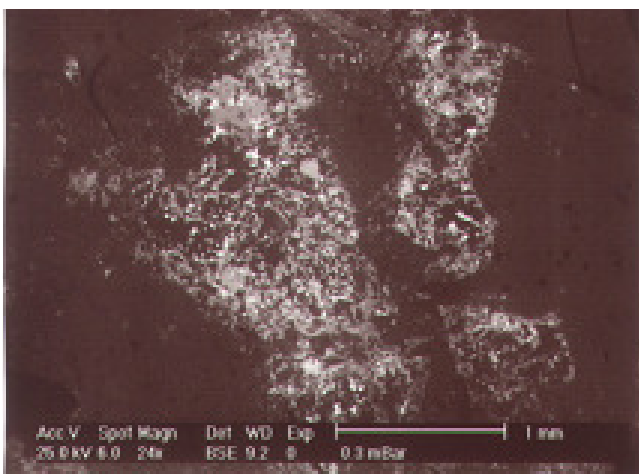

Fig.21: Secondary hematite after aegirine-augite, SEM

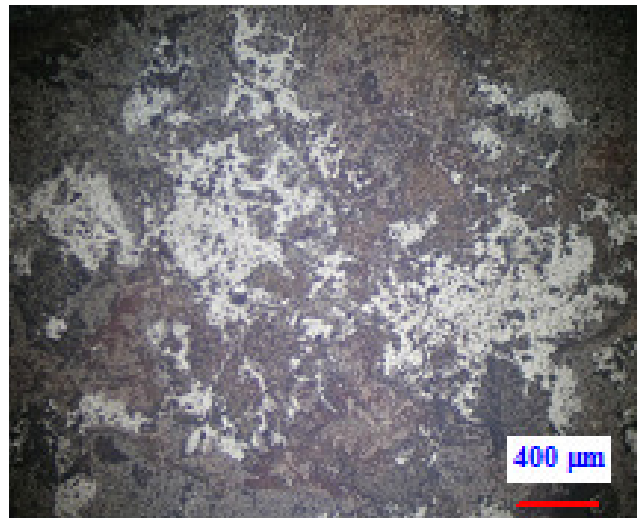

Fig.22: Patches of hematite, RL

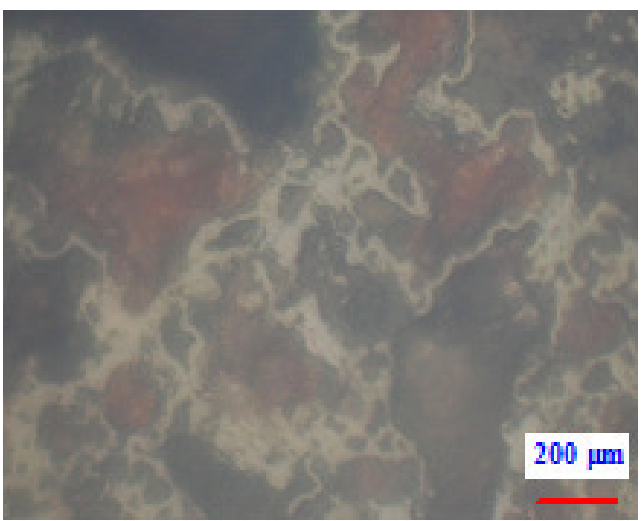

Fig.23: Aegirine-augite rimmed by intergranular film of hematite, $\mathrm{RL}$ 


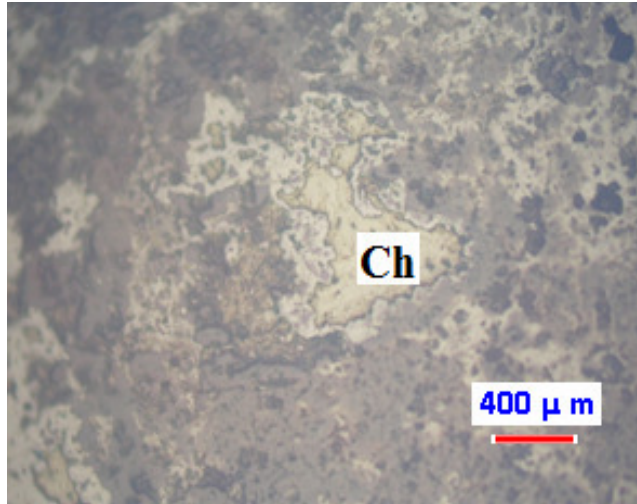

Fig.24: Chalcopyite (Ch) disseminated in hematite, RL

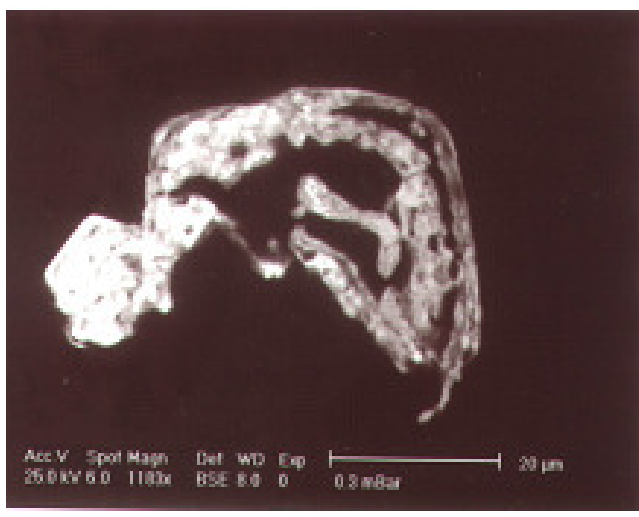

Fig.25: pyrite cube altered to goethite, SEM

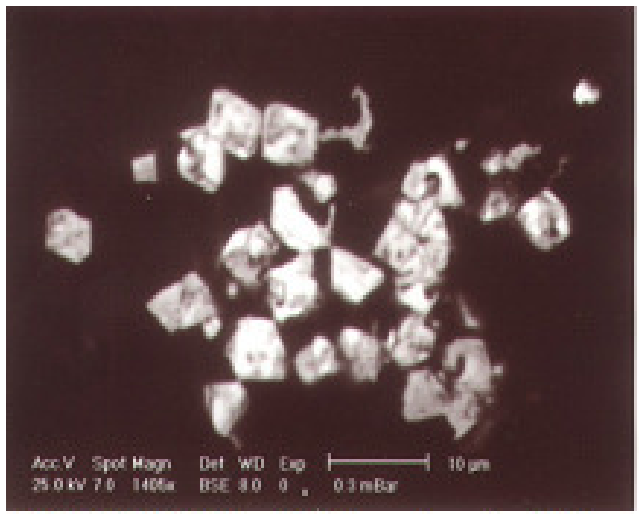

Fig.26: Euhedral to suhedral pyrite grains, SEM

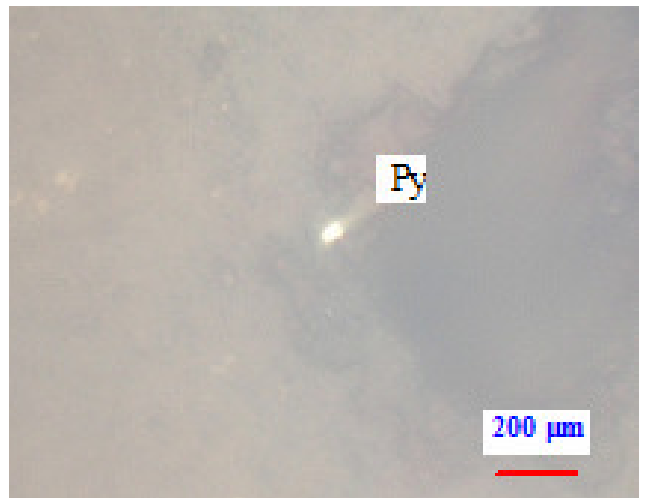

Fig.27: Minute specks of pyrrhotite (Py), RL

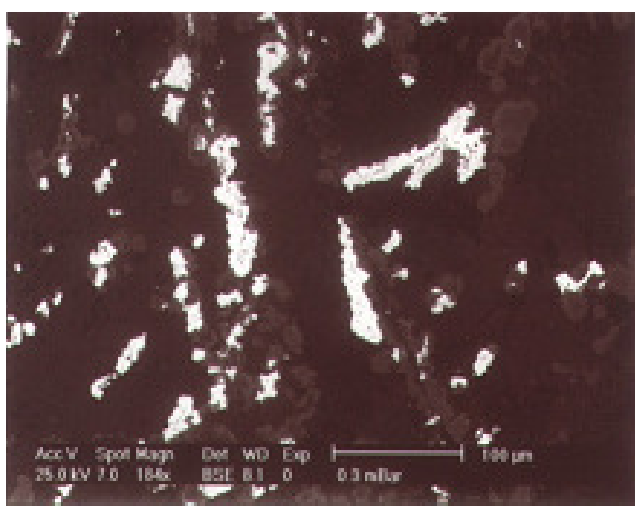

Fig.28: Skeletal prismatic crystals of ilmenite, SEM

oxides show distinctive with intensive sets of tracks that have a well defined outer boundary (Figs.29 to 36) indicating that, it contains great amount of radio-elements ( $\mathrm{U}$ and $\mathrm{Th}$ ).

\section{RADIOACTIVITY}

The radiometric survey for the study area is carried out on a systematic grid with lines interval about $25 \mathrm{~m}$ using a gamma-ray spectrometer instrument (model RS-230 BGO Super-Spec) portable radiation detector accompanying with GPS logger from independent private company (Radiation Solutions Inc, 386 Watline Ave, Mississauga, Ontario, Canada, L4Z $1 \times 2$ ). This instrument measures the total counts, eU and eTh in ppm, $\mathrm{k} \%$ as well dose rate. Seventeen samples representing alkaline 


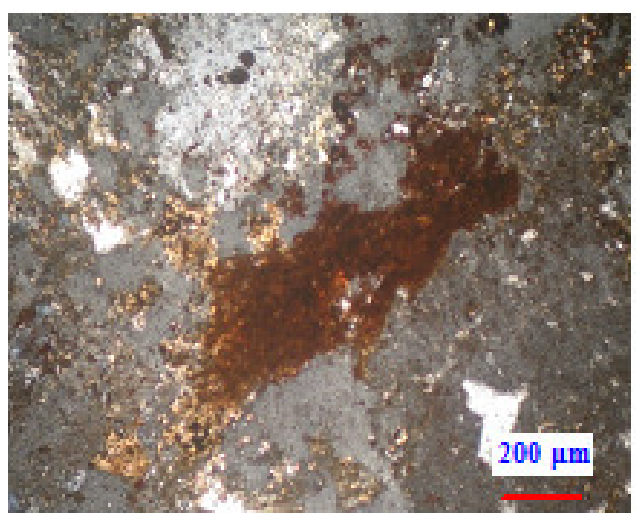

Fig.29: Interstitial iron oxides, alkaine granite, XPL

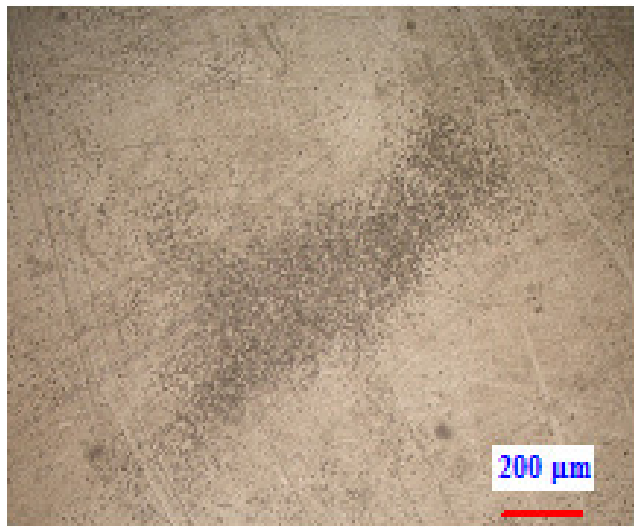

Fig. 30: The equivalent $\alpha$-tracks

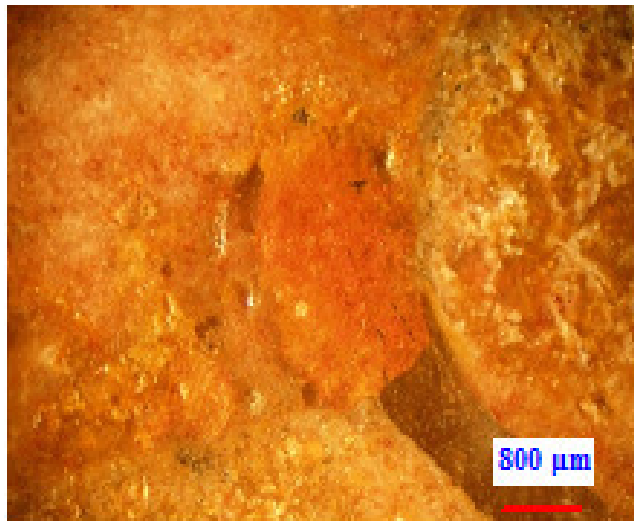

Fig. 31: Altered feldspar, alkaline granite. Polished slab

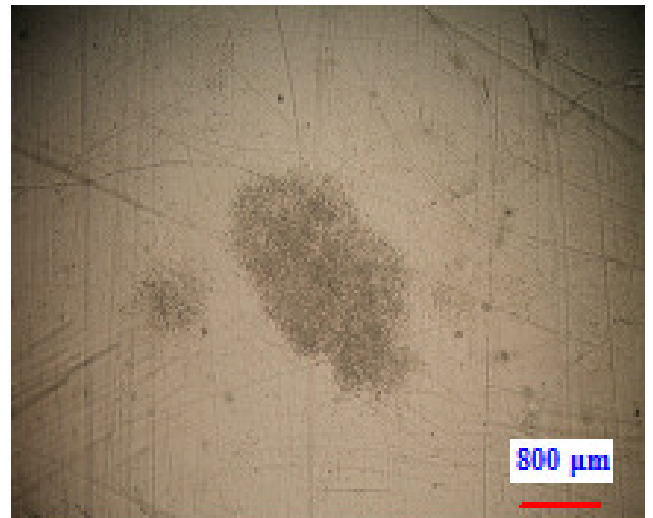

Fig.32: The equivalent $\alpha$-tracks

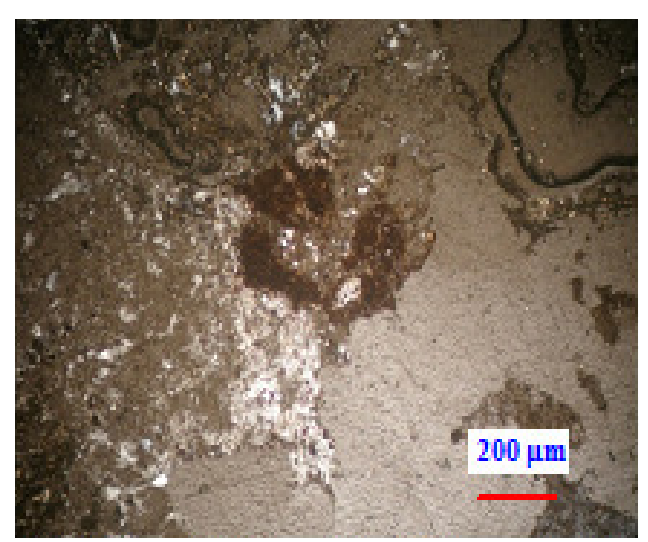

Fig.33: Interstitial iron oxides, alkaline granite, XPL

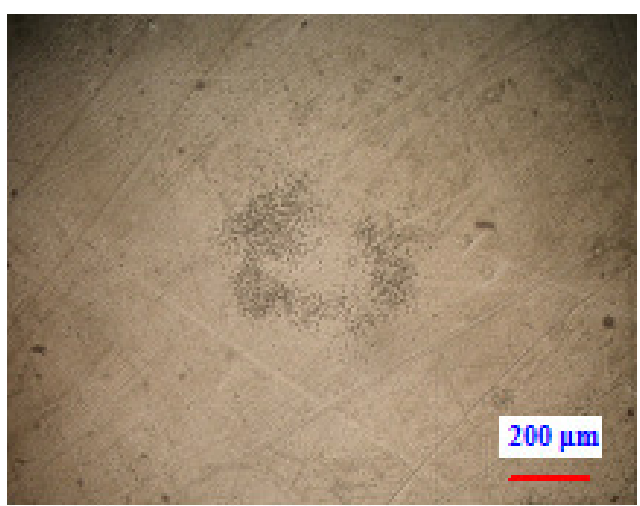

Fig.34: The equivalent $\alpha$-tracks 


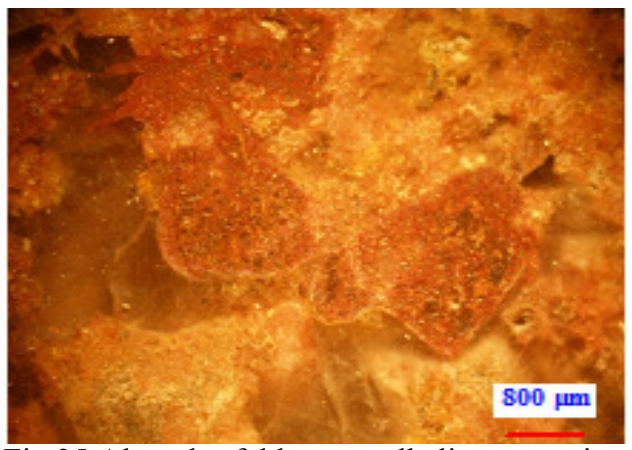

Fig.35:Altered feldspar, alkaline granite. Polished slab

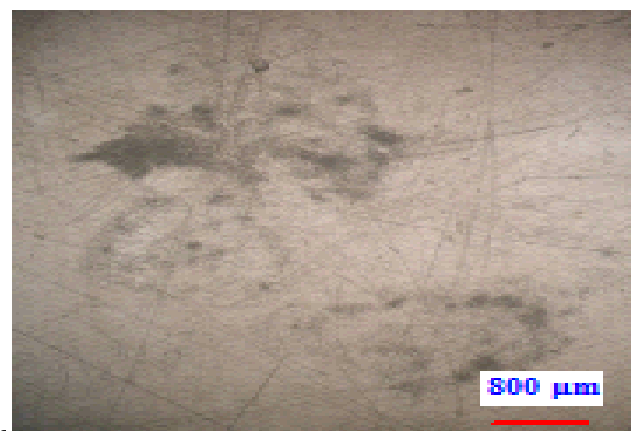

Fig.36: The equivalent $\alpha$-tracks traced the periphery of the stained altered feldspar granite were radiometrically measured in the field in order to determine eU, eTh and $\mathrm{K} \%$ contents quantitatively (Table 1). The measurements indicate that $\mathrm{eU}$, eTh and $\mathrm{K}$ contents increase from the older volcanic rocks to alkaline granites. Thorium is about three times as abundant as uranium in granitic rocks (Rogers and Adams, 1969). Any disturbance in this ratio suggests post-magmatic redistribution of U. Table (1) shows that the majority of the studied alkaline granite samples have eTh/ eU ratio $<3$ indicating some $U$ enrichment.

Results of field spectrometric survey are illustrated in the form of contour map for eU, eTh and K\% respectively (Figs 37, 38 and 39). Both the Uranium and Thorium contour maps (Fig. 37 and 38) show concentration increase in the main fault trend NE-SW, which suggest that the enrichment of $U$ is structurally controlled. On the other hand, K \% contour map (Fig.39) shows that $\mathrm{K}$ concentrates in nearly NW-SE trend nearly perpendicular to that of $\mathrm{U}$ and Th which may be attributed to another phase of alteration.

Also, the content of uranium and thorium in selected 5 samples of alkaline granites

Table 1: Radiometric measurements $\mathrm{K} \%$; eU and eTh contents (ppm); in addition with chemical measurements (for 5 selective samples) of $U$ and Th (ppm) as well as their ratios of alkaline granites in the study area

\begin{tabular}{llrrrrrrrrr}
\hline S. No. & Rock type & K\% & eU & eTh & $\begin{array}{r}\text { eU/eT } \\
\text { h }\end{array}$ & $\begin{array}{r}\text { eTh/e } \\
\text { U }\end{array}$ & U & Th & $\begin{array}{r}\text { U/T } \\
\text { h }\end{array}$ & $\begin{array}{r}\text { Th/ } \\
\text { U }\end{array}$ \\
\hline $\mathbf{1}$ & Alk.granite & $\mathbf{8 . 1}$ & $\mathbf{5 7}$ & $\mathbf{1 4 3}$ & $\mathbf{0 . 3 9}$ & $\mathbf{2 . 5 1}$ & & & & \\
$\mathbf{2}$ & Alk. granite & $\mathbf{1 . 4}$ & $\mathbf{1 3}$ & $\mathbf{2 6}$ & $\mathbf{0 . 5 0}$ & $\mathbf{2 . 0 0}$ & & & & \\
$\mathbf{3}$ & Alk. granite & $\mathbf{4 3}$ & $\mathbf{3 8}$ & $\mathbf{8 6}$ & $\mathbf{0 . 4 4}$ & $\mathbf{2 . 2 6}$ & & & & \\
$\mathbf{4}$ & Alk. granite & $\mathbf{5 . 9}$ & $\mathbf{3 0}$ & $\mathbf{8 1}$ & $\mathbf{0 . 3 7}$ & $\mathbf{2 . 7 0}$ & & & & \\
$\mathbf{5}$ & Alk. granite & $\mathbf{7 . 8}$ & $\mathbf{1 5 5}$ & $\mathbf{4 5 3}$ & $\mathbf{0 . 3 4}$ & $\mathbf{2 . 9 2}$ & $\mathbf{1 2 5}$ & $\mathbf{7 0}$ & $\mathbf{1 . 7 9}$ & $\mathbf{0 . 5 6}$ \\
$\mathbf{6}$ & Alk. granite & $\mathbf{1 . 5}$ & $\mathbf{1 6}$ & $\mathbf{2 4}$ & $\mathbf{0 . 6 7}$ & $\mathbf{1 . 5 0}$ & & & & \\
$\mathbf{7}$ & Alk. granite & $\mathbf{3 0}$ & $\mathbf{1 2 0}$ & $\mathbf{4 0 7}$ & $\mathbf{0 . 2 9}$ & $\mathbf{3 . 3 9}$ & $\mathbf{1 3 0}$ & $\mathbf{5 2}$ & $\mathbf{2 . 5 0}$ & $\mathbf{0 . 4 0}$ \\
$\mathbf{8}$ & Alk. granite & $\mathbf{2 2 . 6}$ & $\mathbf{9 2}$ & $\mathbf{3 1 9}$ & $\mathbf{0 . 2 9}$ & $\mathbf{3 . 4 7}$ & $\mathbf{1 2 2}$ & $\mathbf{5 0}$ & $\mathbf{2 . 4 4}$ & $\mathbf{0 . 4 1}$ \\
$\mathbf{9}$ & Alk. granite & $\mathbf{1 . 8}$ & $\mathbf{2 6}$ & $\mathbf{3 7}$ & $\mathbf{0 . 7 0}$ & $\mathbf{1 . 4 2}$ & & & & \\
$\mathbf{1 0}$ & Alk. granite & $\mathbf{2 . 1}$ & $\mathbf{2 0}$ & $\mathbf{4 4}$ & $\mathbf{0 . 4 5}$ & $\mathbf{2 . 2 0}$ & & & & \\
11 & Alk. granite & $\mathbf{1 0}$ & $\mathbf{5 4}$ & $\mathbf{1 5 4}$ & $\mathbf{0 . 3 5}$ & $\mathbf{2 . 8 5}$ & $\mathbf{1 0 5}$ & $\mathbf{7 4}$ & $\mathbf{1 . 4 2}$ & $\mathbf{0 . 7 0}$ \\
$\mathbf{1 2}$ & Alk. granite & $\mathbf{1 . 9}$ & $\mathbf{5 9}$ & $\mathbf{2 7 3}$ & $\mathbf{0 . 2 2}$ & $\mathbf{4 . 6 3}$ & $\mathbf{1 5 8}$ & $\mathbf{5 6}$ & $\mathbf{2 . 8 2}$ & $\mathbf{0 . 3 5}$ \\
13 & Alk. granite & $\mathbf{2 . 9}$ & $\mathbf{1 1 . 1}$ & $\mathbf{3 7 . 6}$ & $\mathbf{0 . 2 9}$ & $\mathbf{3 . 3 9}$ & & & & \\
14 & Alk. granite & $\mathbf{1 . 4}$ & $\mathbf{4 . 3}$ & $\mathbf{1 4 . 1}$ & $\mathbf{0 . 3 0}$ & $\mathbf{3 . 2 8}$ & & & & \\
15 & Rhyolite & $\mathbf{1 . 2}$ & $\mathbf{7 . 2}$ & $\mathbf{2 0 . 9}$ & $\mathbf{0 . 3 4}$ & $\mathbf{2 . 9 0}$ & & & & \\
16 & Tuffs & $\mathbf{2 . 6}$ & $\mathbf{4 . 9}$ & $\mathbf{1 5 . 9}$ & $\mathbf{0 . 3 1}$ & $\mathbf{3 . 2 4}$ & & & & \\
17 & Tuffs & $\mathbf{0 . 5}$ & $\mathbf{2 . 2}$ & $\mathbf{6 . 3}$ & $\mathbf{0 . 3 5}$ & $\mathbf{2 . 8 6}$ & & & & \\
\hline
\end{tabular}




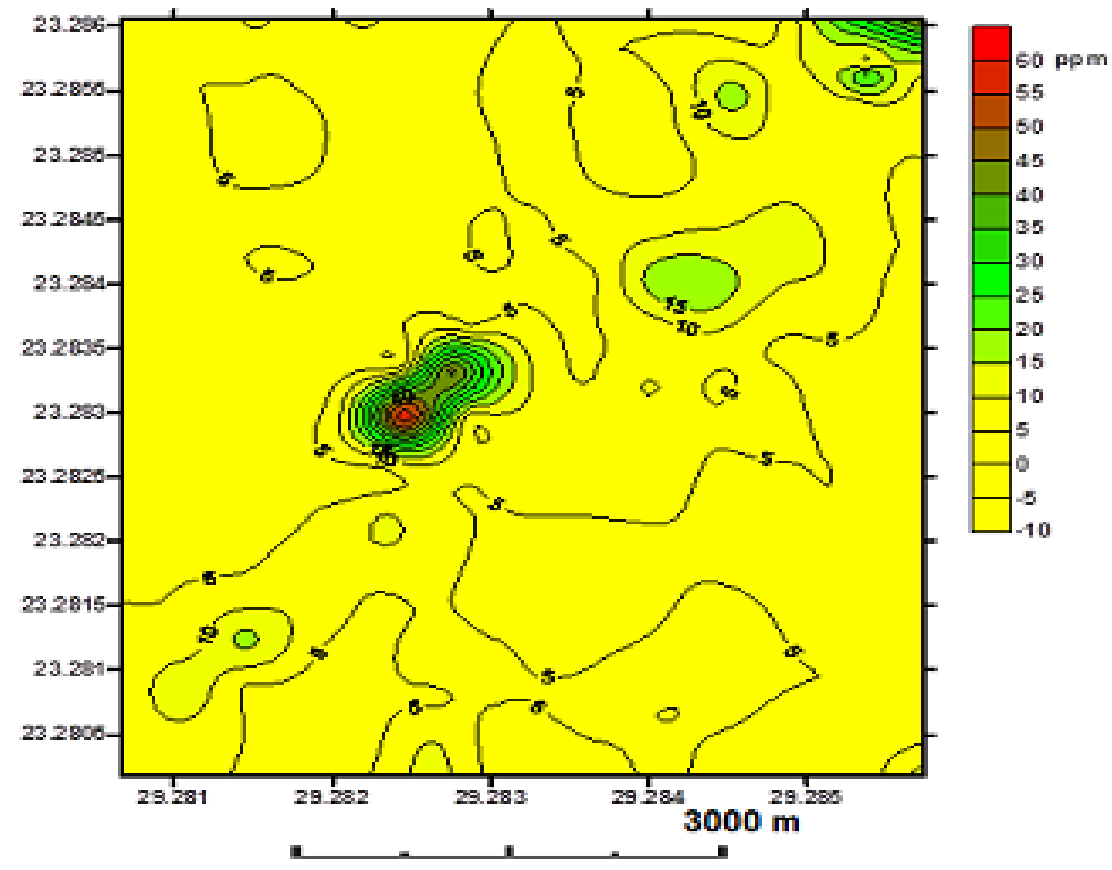

Fig.37: Uranium contour map of southwest Gabal Nusab El Balgoum area

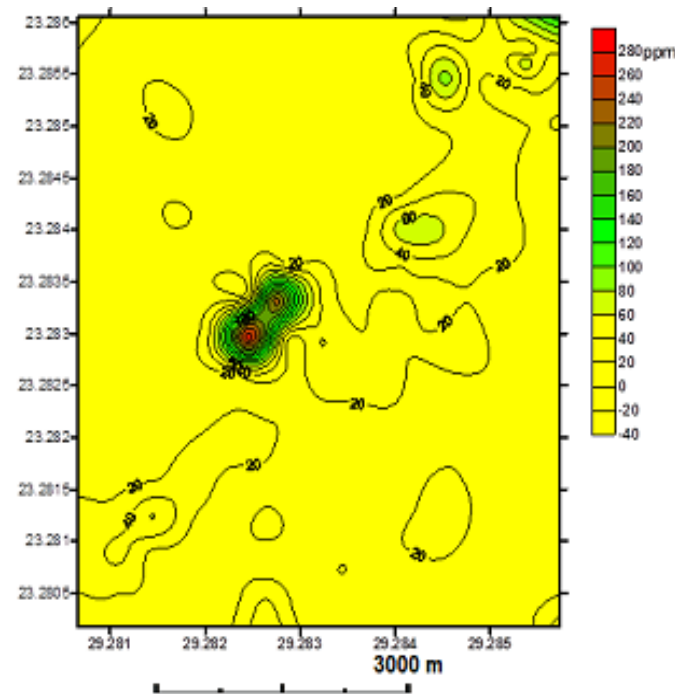

Fig.38: Thorium contour map of southwest Gabal Nusab El Balgoum area

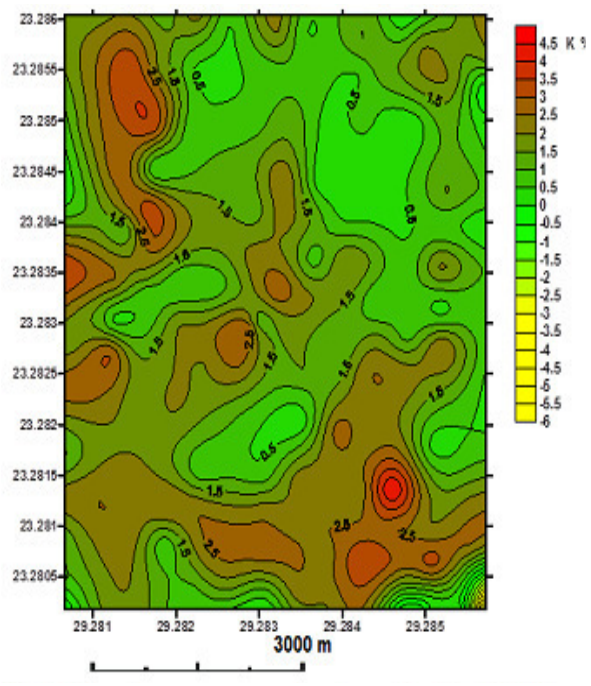

Fig.39: Potassium contour map of southwest Gabal Nusab El Balgoum area 
were chemically measured by Arsenazo III ( extraction method for uranium and precipitation method for thorium), (Marczanko 1986), through the spectrometer colorimetric technique, in the laboratories of the Nuclear Materials Authority, to compare the results with the field measurements (Table 1). The above mentioned data (Table 1) are represented graphically as a bar diagrams (Figs. 40) to compare between the radioactivity of alkaline granite samples recognized in the field and those measured in the lab for the study area.

On contrast with the field measurements, the chemical analysis data shows that the alkaline granites have a higher uranium content (105-158 ppm) and lower thorium content (52$74 \mathrm{ppm})$, Also, the U/Th ratio of all selective samples $>1$, suggesting $U$ enrichment in alkaline granite samples. This contradiction between radioactivity measured in both field and lab can be explained due to recent $U$ addition (the daughters which emit gamma-ray are not produced yet or at least, the decay series did not reach the equilibrium state).

The D-factor first defined by Hansink (1976), is the ratio between the chemical and the radiometric measured uranium. If the $d-$ factor was more or less than unity, it indicates addition or removal of uranium respectively (Hansink, 1976 and Stuckless et al., 1984). It is clear that the chemical uranium of the alkaline granite samples is greater than the radiometric uranium reflecting a case of disequilibrium due to addition of uranium.

\section{Uranium Mobilization}

The equation eU- $(\mathrm{eTh} / 3.5)$ reflects the uranium mobilization. If result of this equation equals zero, it indicates that no uranium mobilization took place (i.e. fresh samples). When it is greater than zero it means that uranium was enriched (added to rock). The negative values mean uranium leaching out.

On the mobility diagram, (Fig.41) one alkaline granite sample shows eU-(eTh/3.5) values less than zero, while the majority of the studied samples have values equal and above zero reach up to 20 . This indicates that alkaline granites are subjected to local U-enrichment especially along shear zones and / or near the contact with the adjacent rocks.

Also, the mobility diagram (Fig.42) show $\mathrm{U}-(\mathrm{Th} / 3.5)$ values above zero and sometimes reaches up to 150 , which indicate that the alkaline granites are subjected to local

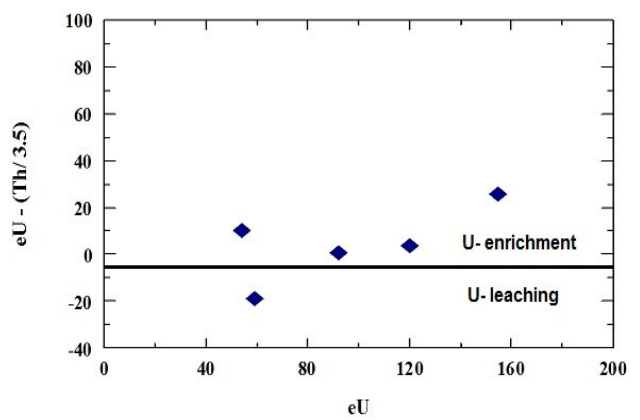

Fig. 41: Uranium mobilization in the alkaline granites in the study area. (field measurements)

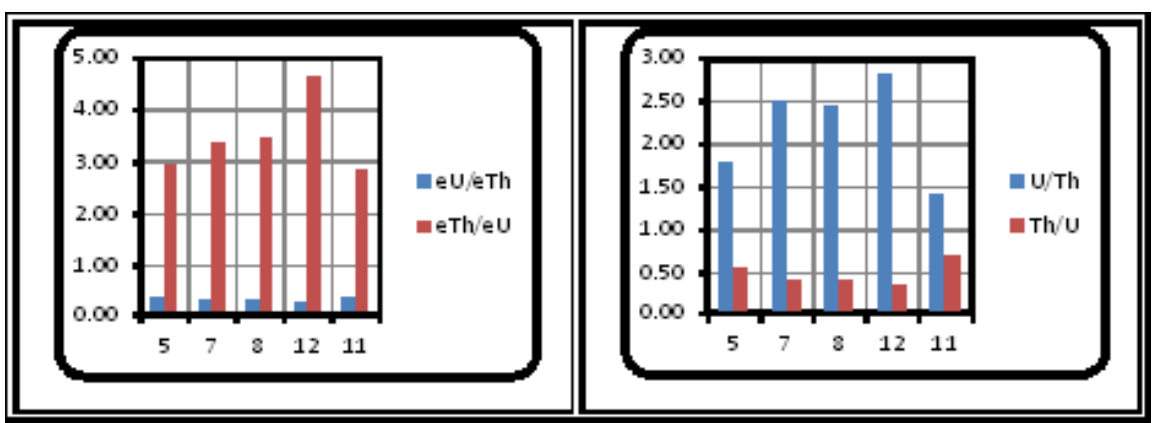

Fig 40: Bar diagram showing eU/eTh, eTh/eU and U/Th, Th/U ratios of the alkaline granites encountered in the study area 
U-enrichment especially along shear zones of granite and may be due to hydrothermal solutions near the contact with the adjacent rocks. Uranium is transported by hydrothermal fluids as soluble carbonate and fluoride complexes at most alteration zones.

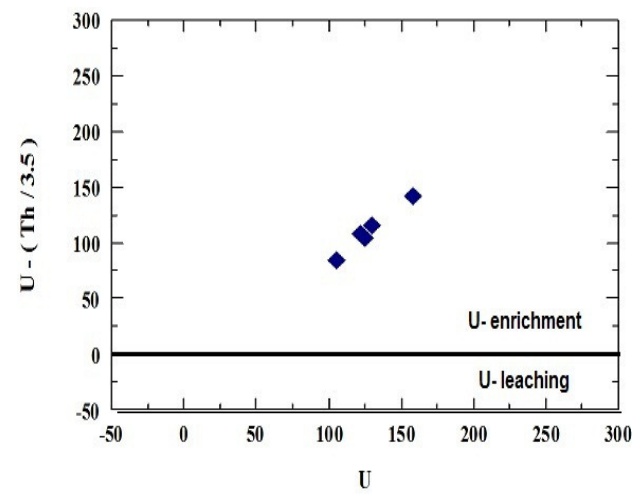

Fig. 42: Uranium mobilization in the alkaline granites in the study area. (Chemically measured)

\section{GEOCHEMISTRY OF U AND TH IN THE STUDY AREA}

The results of the trace elements analysis (Table 2) are confirmed statistically by applying graphical representation as bar diagram (Fig.43). The bar diagram shows that $\mathrm{Zr}, \mathrm{Nb}$, $\mathrm{Y}$ (HFS elements) values increase with increasing $\mathrm{U}$ in the study area.

Plotting of trace elements ( $\mathrm{Zr}, \mathrm{Y}$ and $\mathrm{Rb}$ ) versus $U$ on binary diagrams (Fig. 44, 45 and 46), revealed that all the analyzed samples lie on mineralized field of Wrenich (1984) which consistent with minerals detected in the study area. High values of these elements $(\mathrm{Nb}, \mathrm{Y}$ and $\mathrm{Zr}$ ) can be attributed to the low mobility of these elements in the surficial environment, due to high chemical and mechanical stabilities of their host minerals (bastnaesite, zircon, xenotime, monazite...etc.) against weathering and disintegration. Hence, these minerals tend to be highly concentrated among other heavy minerals near the primary source rocks. This fact is consistent with the results obtained from petrographical study. Rela-
Table 2: Trace elements, REEs concentration (ppm) and REE ratios in alkaline granite.

\begin{tabular}{|c|c|c|c|c|c|}
\hline S.No. & 5 & 7 & 8 & 12 & 11 \\
\hline $\mathrm{Cr}$ & 73 & 14 & 23 & 9 & 66 \\
\hline $\mathrm{Ni}$ & 2 & 2 & 2 & 2 & 7 \\
\hline $\mathrm{Cu}$ & 4 & 2 & 2 & 4 & 6 \\
\hline Zn & 327 & 296 & 354 & 371 & 365 \\
\hline $\mathrm{Zr}$ & $>10000$ & $>10000$ & $>10000$ & 7856 & $>10000$ \\
\hline $\mathbf{R b}$ & 2 & 128 & 119 & 2 & 81 \\
\hline Y & 4925 & 8216 & 9186 & 511 & 4427 \\
\hline Ba & 519 & 180 & 309 & 1262 & 555 \\
\hline $\mathrm{Pb}$ & 185 & 150 & 141 & 91 & 52 \\
\hline $\mathrm{Sr}$ & 466 & 773 & 897 & 10000 & 432 \\
\hline Ga & 16 & 37 & 29 & 650 & 11 \\
\hline V & 8 & 3 & 9 & 22 & 10 \\
\hline $\mathrm{Nb}$ & 2139 & 3578 & 4041 & 543 & 1921 \\
\hline La & 150 & 41.7 & 50.8 & 147.1 & 81.5 \\
\hline $\mathrm{Ce}$ & 343.4 & 153.3 & 96.3 & 302.8 & 187.1 \\
\hline Pr & 14.4 & 18 & 10.1 & 18.9 & 20.4 \\
\hline Nd & 59 & 49 & 26 & 102.2 & 66.5 \\
\hline Sm & 22 & 8.2 & 10.5 & 38.9 & 33 \\
\hline Eu & 1.05 & 0.7 & 0.8 & 1.7 & 1.2 \\
\hline Gd & 21.3 & 8.9 & 5.9 & 29.6 & 8.9 \\
\hline $\mathrm{Tb}$ & 2.4 & 0.9 & 1 & 2.4 & 2.1 \\
\hline Dy & 7.9 & 5.6 & 4.4 & 7.4 & 5.4 \\
\hline Ho & 1.3 & 0.57 & 0.64 & 1.7 & 1 \\
\hline Er & 2.9 & 1.5 & 1.8 & 3.8 & 3 \\
\hline $\mathrm{Tm}$ & 0.52 & 0.2 & 0.23 & 0.6 & 0.41 \\
\hline $\mathbf{Y b}$ & 2.8 & 1.6 & 1.41 & 3.6 & 3.2 \\
\hline Lu & 0.3 & 0.17 & 0.2 & 0.5 & 0.41 \\
\hline $\mathrm{La} / \mathrm{Lu}$ & 500.0 & 245.3 & 254.0 & 294.2 & 198.8 \\
\hline $\mathrm{Th} / \mathrm{U}$ & 0.6 & 0.4 & 0.4 & 0.4 & 0.7 \\
\hline $\mathrm{La} / \mathrm{Yb}$ & 53.6 & 26.1 & 36.0 & 40.9 & 25.5 \\
\hline $\mathrm{Tb} / \mathbf{Y b}$ & 0.86 & 0.56 & 0.71 & 0.67 & 0.66 \\
\hline
\end{tabular}

tion between uranium and thorium is helpful to test if there is enrichment or depletion of these elements. Plotting U vs Th (Fig.47) show that all the analyzed samples located under the line $\mathrm{Th} / \mathrm{U}=1$ (after Wenrich, 1984) indicating uranium enrichment in all samples of alkaline granite, while plotting $\mathrm{U}$ vs. Th/ U (Fig.48) clear that all samples of the study area lie under $\mathrm{Th} / \mathrm{U}=1$ indicating uranium enrichment than thorium.

\section{RARE EARTH ELEMENTS $\left(\right.$ REE $\left._{\mathrm{S}}\right)$}

The REEs are useful geochemical tool to give valuable information about rock genesis. The REE data of all selected alkaline granite samples are normalized against chondrite 


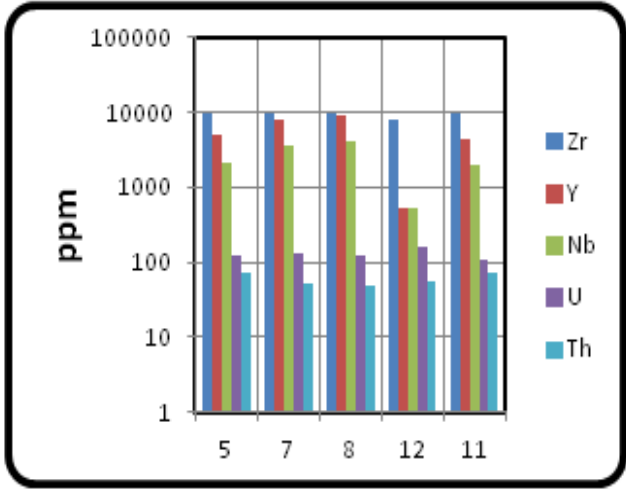

Fig. 43: Bar diagram showing the average of $U$ and $\mathrm{Th}$ and some trace elements measured in alkaline granite of Nusab El Balgoum area.

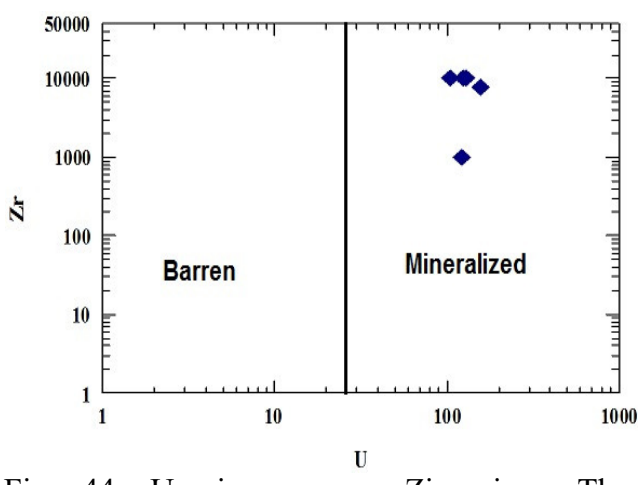

Fig. 44: Uranium versus Zirconium. The mineralized and barren fields are from Wenrich, 1984.

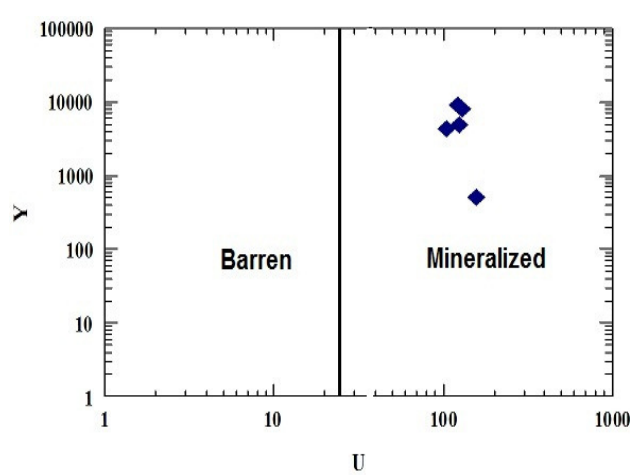

Fig.45: Uranium versus yttrium. The mineralized and barren fields are from Wenrich, 1984

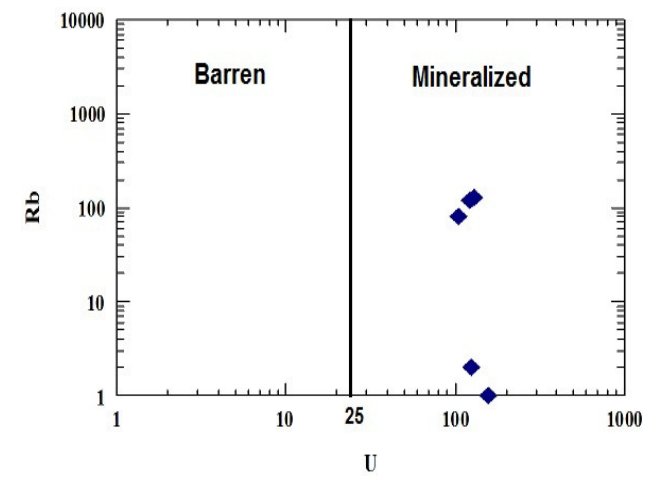

Fig.46: Uranium versus Rubidium.The mineralized and barren fields are from Wenrich, 1984

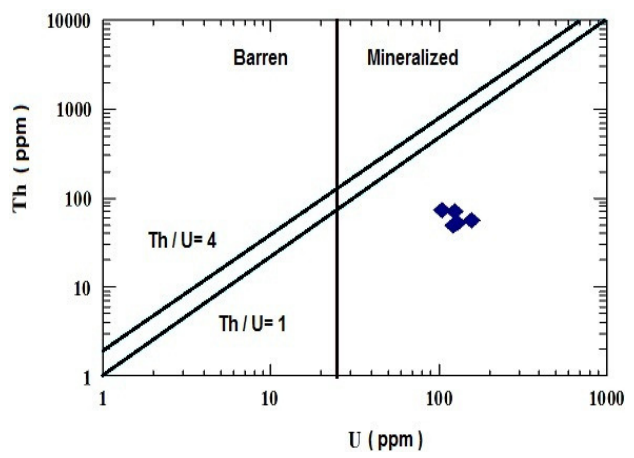

Fig. 47: Uranium versus Thorium. The mineralized and barren fields are from Wenrich, 1984

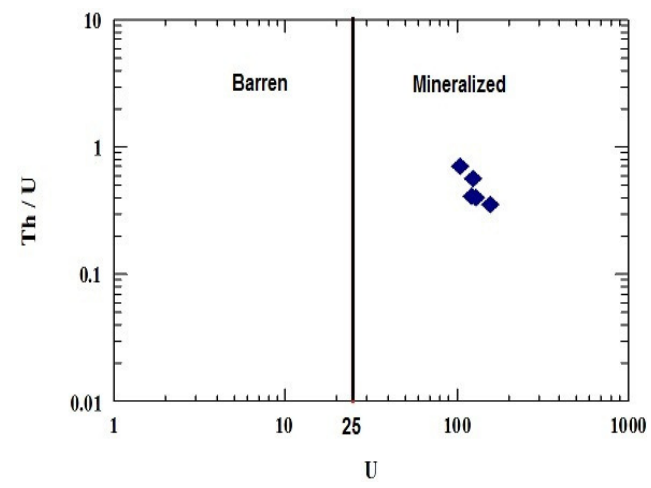

Fig. 48: Uranium versus thorium/uranium ratio. The mineralized and barren fields are from Wenrich, 1984 
values of Hendrson (1996). Chondrite normalized REE diagram (Fig.49) shows that the alkaline granite of the studied area display progressive enrichment in LEE relative to HREE which shows a slightly flat pattern with large negative Eu anomaly. This Eu anomaly are caused by crystal fractionation of plagioclase in the magma chamber, the $\mathrm{Eu}^{2+}$ ion can substitute for $\mathrm{Ca}^{2+}$ in the plagioclase because of its similarity in radius (Faure, 1998). The concentrations and distribution of REEs in natural deposits are dependent on several petrogenetic processes, including enrichment and complexion in late-stage magmatic or hydrothermal fluids, fractionations into mineral phases, oxidation or reduction, and redistribution during weathering. The $\mathrm{La} / \mathrm{Lu}, \mathrm{La} / \mathrm{Yb}$, $\mathrm{Tb} / \mathrm{Yb}$ ratios (Table 2) indicate that the alkaline granite of the studied area display high LREE enrichment relative to HREE due to the presence of bastnaesite and monazite as a source of LREE and xenotime as a source for HREE which concides with the results of petrographical studies (Figs.19, 20 and 18 respectively). A brief account on REEs bearing minerals (bastnaesite, monazite and xenotime) in the study area as follows :

Bastnaesite $\left[(\mathrm{Ce}, \mathrm{La})\left(\mathrm{CO}_{3}\right) \mathrm{F}\right]$, a cerium fluoride carbonate found in contact metamorphic zones and pegmatites; cerium is commonly substituted by light rare earths, lanthanum, yttrium, and thorium. It ranges in colour from wax-yellow to reddish-brown. Bastnaesite is commonly associated with other rareearth-bearing minerals such as allanite, cerite, and tysonite; it is often an alteration product of tysonite. It occurs predominantly in calcsilicate rich rocks related to alkaline intrusive igneous complexes, and to a lesser extent, in quartz veins, epithermal fluorite-bearing veins and breccia fillings, (Encyclopedia Britannica). Monazite [(Ce,La,Nd,Th $\left.)\left(\mathrm{PO}_{4}\right)\right]$ $\left[(\mathrm{REE}) \mathrm{PO}_{4}\right]$ is a reddish-brown phosphate mineral containing rare earth metals. It occurs usually in small isolated crystals forming the principal ore of thorium, containing up to $30 \%$ Th, which together with smaller

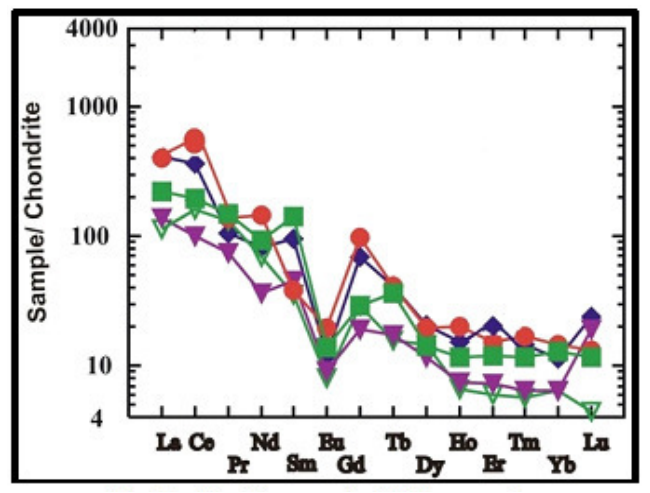

Fig. 49: Chondrite normalized REE pattern for alkaline granite of the studied area

(up to $\sim 1 \%$ ) quantities of $U$ imparts radioactive properties to the monazite. Bastnaesite and monazite are sources of the light REE and account for about $95 \%$ of the REE currently utilised. Xenotime $\left(\mathrm{YPO}_{4}\right)$, is widely distributed phosphate mineral, yttrium phosphate, though large proportions of erbium commonly replace yttrium, that occurs as brown, glassy crystals, crystal aggregates, or rosettes in igneous rocks and associated pegmatites. Monazite and xenotime occur as accessory minerals in low-Ca granitoid rocks and pegmatites. Xenotime is commonly associated with zircon, being isostructural and often found enclosing zircon (Christie et al.,1998).

\section{DISCUSION AND CONCLUSIONS}

Using alpha-track emission indicates that iron oxides and altered feldspar minerals contain great amount of radio-elements ( $U$ and Th). Iron oxides show intensive sets of tracks that have a well defined outer boundary indicating that, it contains great amount of radioelements ( $\mathrm{U}$ and $\mathrm{Th}$ ). Illustrating the results of field spectrometric survey in the form of contour map for eU, eTh (ppm) and K (\%) indicate that both uranium and thorium concentrate in the main fault trend NE-SW, which suggest that the enrichment of $U$ is structurally controlled.

A comparison between field measure- 
ments (eU and eTh) with the chemical analysis data ( $U$ and $T h$ ) shows that the alkaline granites have a higher uranium content (105$158 \mathrm{ppm}$ ) and lower thorium content (52-74 $\mathrm{ppm}$ ), whereas the U/Th ratio of all selective samples $>1$, suggesting $U$ enrichment in alkaline granite samples. This contradiction between radioactivity measured in the field and those chemically measured in the lab can be explained due to recent $\mathrm{U}$ addition (the daughters which emit gamma-ray are not produced yet or at least, the decay series did not reach the equilibrium state).

The presence of the iron oxy-hydroxides alteration (hematite and goethite) as recognized from opaque minerals study, which is the main alteration process, help us to understand the contradiction of enrichment in $U$ content measured chemically in comparison with radiometric field measurements which may be due to the high ability of iron oxides to adsorb uranium from its bearing solution (Hussein et al., 1965) and/or the prevalence of oxidation conditions and complexing ions, that cause precipitation of uranium as complex uranyl ions (Cuney, 2003). The nature of uranyl ions may also help in uranium transportation particularly when the $\mathrm{pH}$ of the fluids is relatively low (Langmuir, 1978). The leached uranium may represent the main source of uranium that added in alkaline granites.

The obtained results of the trace elements analysis statistically treated using bar diagram showing that $\mathrm{Zr}, \mathrm{Nb}, \mathrm{Y}$ (HFS elements) values increase with increasing $U$ in the study area as a result of hydrothermal alteration at later stages of magmatic activity. Plotting the results of trace elements analysis against uranium revealed that all the analyzed samples lie on mineralized field (after Wenrich, 1984), while all selected samples plotted under the $\mathrm{Th} / \mathrm{U}=1$ field, reflecting uranium enrichment in all alkaline granite samples. Besides, applying REEs data on Chondrite normalized REE diagram shows that the alkaline granite display progressive enrichment in LEE relative to HREE with a slightly flat pattern and large negative Eu anomaly, which may be attributed to the presence of Bastnaesite and monazite as a source of LREE and xenotime as a source for HREE which coincides with the results of petrographical studies.

Generally, the study area needs more detailed work to evaluate the recent uranium deposits as shown from the difference in uranium content between field measurements and chemical analysis. As well as, detecting the source of $U$ deposits and the trend of leaching solution to precipitate in the study area.

\section{Acknowledgements}

We wish to thanks to Dr. Assran, H. , Dr. Abu El Atta, S. and Dr. Ahmed, A. for helping us during fieldwork.

\section{REFERENCES}

Abd El Warith, A. (1997): Mineralogical, petrographical and geochemical studies of the radioactive occurrences in the volcanic rocks, Nusab El Balgum area, South Western Desert, Egypt., M.Sc. Thesis, Cairo Univ., 178p.

Abu El Atta, S.A., Assran, H.M. and Ahmed, A.A. (2013): Preliminary study on HFSE mineralization in the peralkaline granites of Nusab El Balgum area, South Western Desert, Egypt, Geomaterials, 3, 90-101.

Assran H.M., Hamed A.A., Arbab A.A., Ahmed A.A., Moghazy, N.M. and Abdallah S.A. (2012): Reconnaissance radiometric survey in Bir Safsaf-Nusab El Balgum area, South Western Desert, Egypt, Scientific Internal Report, Nuclear Materials Authority, Cairo, Egypt.

Bishady, A.M. and El Ramly, M.F. (1982): Petrographical and petrochemical studies of some alkaline volcanics from Uweinat area, South Western Desert, Egypt. Ann. Geo. Surv. Egy., XII, 29-45.

Christie A.B., Brathwaite, R.L., Tulloch, A.J. (1998): Mineral commodity report 17; rare earths and related elements. New Zealand Mining 24 (Pages 7-19).

Cuney, M. (2003): Mechanisms of U-fractionation. 
U solubility controls in silicate melts and fluid phase, partial melting and fractional crystallization. IAEA short course.

El Shazly E.M., Assaf, H.S. and El Kassas, I.A. (1969): The radioactive mineralization of south west Aswan, Internal Report Geol. And Nuclear Raw Mat. Dept. Atom. Energy Establishment, Cairo, 35p.

Encyclopedia Britannica: http://www.britannica. com/EBchecked/topic/HYPERLINK "http:// www.britannica.com/EBchecked/topic/55639/ bastnaesite"55639HYPERLINK "http://www. britannica.com/EBchecked/topic/55639/bastnaesite"/bastnaesite

Faure, G. (1998): Principles and Applications of Geochemistry (Vol.2) Prentice Hall.

Frantz, G., Puchelt, H. and Pasteels, P. (1987): Petrology, geochemistry and age relations of Triassic and Tertiary volcanic rocks from SW Egypt and NW Sudan. J. African Earth Sci., 6 (3), 335-352.

Hansink, J.D. (1976): Equilibrium analyses of sandstone roll front uranium deposits. International Atomic Energy Agency, Vienna, 683-693.

Henderson, P. (1996): Rare earth elements, introduction and review. In: Jones, A.P.(Ed), Rare earth minerals. Chemistry, origin and deposits.

Hussein, H. A., Faris, M. I. and Makram, W. (1965): Radioactivity of some accessory minerals especially zircon in some Egyptian granites and pegmatites. Jour. Geol., 9 (2), 13-16.

Klitzsch, E. and Schandelmeire, H. (1990): The geology of Egypt, Edited by Rushdi Said published by A.A. Blkema/Rotterdam/Brookfield.

Langmuir, D. (1978): Uranium solution-mineral equilibria at low temperatures with applications to sedimentary ore deposits. Geochim. Cosmochim. Acta, 42, 547-569.

Marczanko, Z. (1986): Separation and spectrophotometric determination of elements. Halsted press: a division of John Willy and sons New York, 677p.

Richter, A. and Schandelmeier, H. (1990): Precambrian basement Inliers of Western Desert Geology. Petrology and Structural Evolution. In Said, R. (ed). The Geology of Egypt, A.A. Balkema, 185-200.

Richter, A. (1986): Geologic der metamorphen und magmatischen Gesteine in Gebiet Zwischen Gebel Uweinat und Gebel Kamel. SW Agypten, NW Sudan. Berl. Geowiss. Abh., 73 (A), 1-201.

Rogers, J.J.W. and Adams, J.S.S. (1969): Uranium. In: Wedepohl, K. H. (ed.) Handbook of geochemistry, New York, Springer-Verlag, 4, 92 B1- 92 C10.

Sakran Sh.M., Abdel Kader Z., Morsy M.A. and Mohamed A.A. (1996): Geological and Structural Studies on the Triassic volcanics and the younger peralkaline granite of Nusab El -Balgum area, south Western Desert, Egypt. Third Int. Conf. Geol of the Arab world, Cairo Univ., 201-213.

Stuckless, J.S., Nkomo, I.T., Wenner, D.B. and Van Trump. G. (1984): Geochemistry and uranium favourability of the postorogenic granites of the northwestern Arabian Shield. Kingdom of Saudi Arabia. In: Pan-African crustal evolution in the Arabian-Nubian Shield (Convenor: A. M. Al Shanti), Bull. Fac. Earth Sci., king Abdelaziz Univ., Jeddah, Pergamon Press, Oxford, 195-210

Vail, J.R. (1976): location and geochemistry of igneous ring complexes and related rocks in northeast Africa. Geol. Jb. 20 (B), 97-114.

Vail, J.R. (1985): Alkaline Ring Complexes in Sudan. Jour. Afri. Earth Sci., 3, 51-59.

Wenrich, K.J. (1984): Mineralization of breccia pipes in northern Arizona [abs.], in Bogdanov, N.A., (ed.), Special session of the International 'Lithosphere' Programme: International Geological Congress, $27^{\text {th }}, 9,380-381$. 


\section{جيولوجية واشعاعية الجرانيت القلوى جنوب غرب جبل نصاب البلجوم، جنوب الصحراء

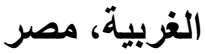

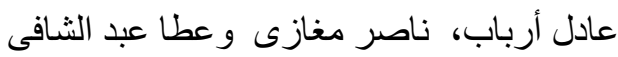

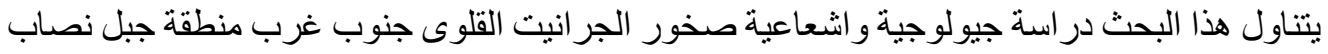

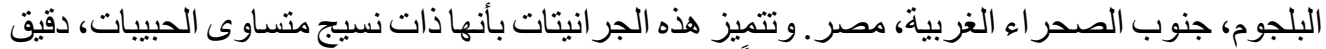

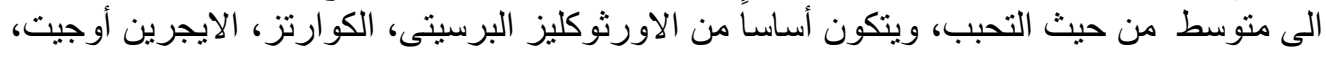

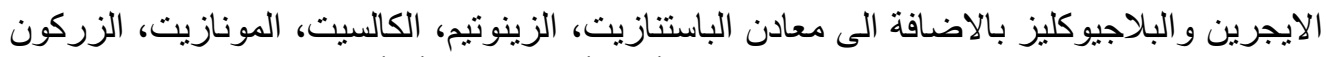

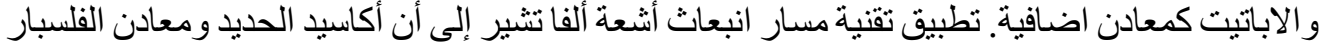

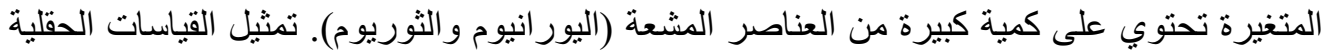

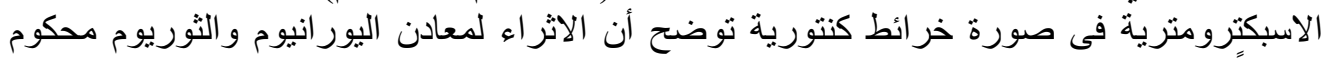

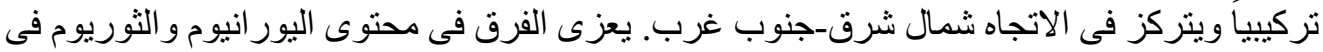

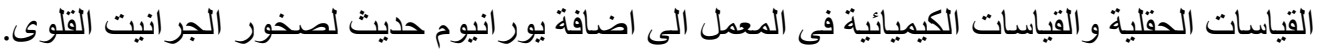

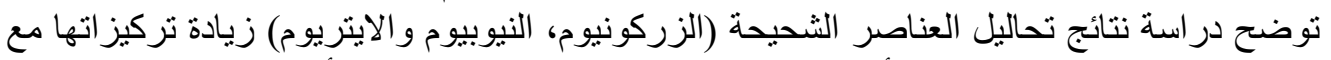

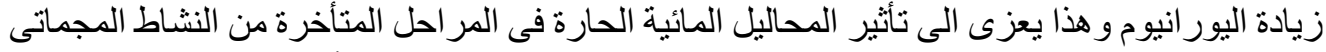

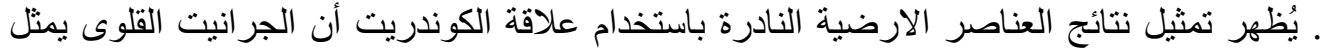

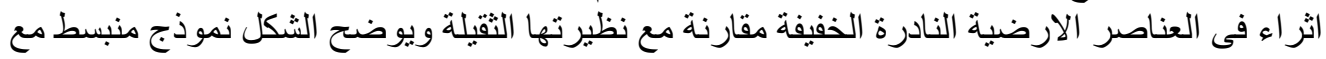

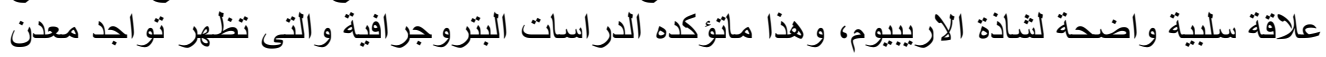

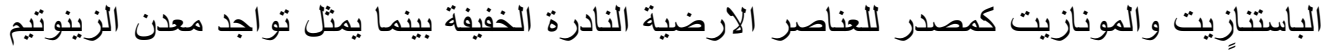

مصدر أللعناصر النادرة الثقيلة. 